\title{
Consumer's Preference and Willingess to Pay for Organic Foods in Osogbo Southwest, Nigeria
}

\author{
Yesufu OA, FJ Aremu*, R Kassali and AA Adebayo \\ Department of Agricultural Economics, Obafemi Awolowo University, Ile Ife, Nigeria
}

Received: 眥 April 20, 2018; Published: 㘹 May 02, 2018

*Corresponding author: FJ Aremu, Department of Agricultural Economics, Obafemi Awolowo University, Ile Ife, Nigeria

\begin{abstract}
Despite millions of smallholder vegetable farmers along the market chain of subsistence agriculture in most developing countries, consumption of organic vegetables in Nigeria has been reported to be significantly low. Consumers' preference for organic vegetable with emphasis on wareness, perception and willingness to pay was studied. One hundred consumers were randomly selected. A questionnaire was used to obtain information on socioeconomic characteristics and other relevant variables. Data were analyzed with descriptive statistics and Spearman ranking. The result showed that there was high awareness of organic vegetable in the metropolis and Consumers were mostly informed through television (27.8\%), radio (23.2\%) and internet (29.3\%). Consumers preferred organic vegetables to conventional ones as it was perceived to be healthier (77\%), of better quality (76\%), tastier (66\%), less harmful (66\%) but expensive (30\%) respectively. There was good supply of organic vegetable in the market and Okro (21.6\%), Amaranths vegetables (20.4\%) and tomato (19.8\%) were the organic vegetables mostly consumed in the metropolis. Health concern $(80 \%)$, satisfaction $(79 \%)$ and safety $(78 \%)$ respectively are the major reasons why consumer opted for organic vegetable. The consumers' familiarity with organic vegetables mostly influences them to be willing to pay premium on the vegetables. Facilities to expand, proper certification and labelling of organic products were recommended to encourage continuous growth of the market.
\end{abstract}

Keywords: Awareness; Perception; Consumers; Organic-Food

\section{Introduction}

Organic foods are foods produced by organic farming. While the standards differ worldwide, organic farming in general features cultural, biological, and mechanical practices that foster cycling of resources, promote ecological balance, and conserve biodiversity [1]. Synthetic pesticides and chemical fertilizers are not allowed, although certain organically approved pesticides may be used under limited conditions. In general, organic foods are also not processed using irradiation, industrial solvents, or synthetic food additives [2]. Fruit and vegetable consumption has grown over the last few years because people are more concerned about staying healthy and eating right. Research into nutraceuticals and functional food has highlighted the health compounds found in fruits and vegetables. There has also been an increase in vegetarian diets and a stronger demand for exotic produce, resulting in a wider and dynamic market during all seasons of the year [3]. Several studies have justified that diets rich in vegetables confer health benefits and may even be protective against the risk of different types of diseases such as diabetes, cancer and strokes [4-6]. According to The World Health Organization [7], low fruit and vegetable intake is estimated to cause about $31 \%$ of Ischaemic heart disease and $11 \%$ of stroke worldwide. Overall it is estimated that up to 2.7 million lives could potentially be saved each year if fruit and vegetable consumption was sufficiently increased. Due to increasing concerns about food safety and environmental quality, organic food has rapidly emerged as an important food industry in many countries of the world and organic vegetable is gradually creating a niche for itself in global market. According to Lia [8] City and sub-district markets are more lucrative and profitable for organic vegetable traders because consumers in those locations are affluent, quality conscious and willing to pay higher prices. A perceived scarcity can result in affluent consumers increasing purchases. Frequent weekly visits 
indicate those consumers prefer markets as the main source of vegetables for their household [9]. Traders have responded to this opportunity by developing appropriate market chains. In response, consumers also express a willingness to pay higher prices for better quality.

This preference is particularly strong with those with a higher education, and those of a younger demographic. Most of who are under age 35 choose organics when possible but price has been found to be the primary reason that consumers preferred nonorganic vegetables. The perceived shortage of commodities and consumers' willingness to pay premium prices for quality provides opportunities for farmers and traders to increase production, processing and marketing of quality commodities [8]. In a study by FAO [9]. The reasons consumers frequently give for not eating more organic vegetable include traditional and individual indifference, high prices and variable availability, their taste, quality and safety. It is a known fact that consumers want foods that are readily available, affordable, convenient to acquire and prepare, socio-culturally appropriate, safe and healthy. Despite the increased awareness of the importance of organic vegetables to healthy living, low intake of this vegetable has been a widespread characteristic among Nigerians [6]. Though studies have shown that many consumers prefer organic foods to conventional foods, price is often a major factor that influences their behavior as organic vegetables are especially price sensitive given its daily consumption $[2,10]$. In spites of the importance of organic vegetables to human health and the environment, there is still a short fall in consumption in the country and which has reduced the availability of organic vegetables in mainstream markets, thus preventing the market from expanding. Similarly, many Nigerian farmers are still hesitant to adopt the production of organic vegetables in large scale due to inadequate information on the consumers' willingness to pay. This research therefore intends to: (a) Identify the consumers' socioeconomic characteristics, (b) Examine the consumers' perception of organic vegetables over conventional vegetables, (c) Assess reasons for consumers' perception of organic vegetables over conventional vegetables (d) Analyzed factors influencing consumers' preference for organic vegetables and (e) Analyzed factors that influence consumers' willingness to pay for organic vegetables.

\section{Willingness to pay (WTP)}

Willingness to pay (WTP) for a commodity is the amount of money a person would be willing to pay for a higher level of environmental or commodity quality. WTP is a measure of the resources individuals are willing and able to give up for a reduction in the probability of encountering a hazard that compromises their health [11]. Spencer [12] opined that a theoretical correct measure of the value individuals attach to improvements in food safety is their 'WTP' for safer food. This, therefore, is the largest amount that an individual is willing to pay for a specific improvement in food safety. The notion of willingness to pay could be defined as the sum of money representing the difference between consumers' surplus before and after adding or improving a food product attribute $[11,13]$. Models that estimate consumers' willingness to pay when adding or enhancing a given quality attributes are based on the Lancaster approach [14], which maintains that consumers directly derive utility from the attributes of goods. According to James [15], tools for measuring WTP (which include the contingent valuation, travel cost and hedonic pricing) can be used to answer questions such as how much consumers are willing to pay for a quality upgrade or what effect a particular government intervention might be. In this regard, consumers' willingness to pay (WTP) for organic food products can be measured using a direct valuation method such as the contingent valuation (CV). The procedure consists of a dichotomous choice (DC) question and a maximum WTP question. In the DC question, consumers are asked whether or not they are willing to pay a premium, to buy an organic vegetable instead of a conventional one. The amount they are willing to pay is a percentage over the price of the conventional product and differs across consumers. Consumers' responses are YES if they are willing to pay more for an organic vegetable or NO otherwise. Consumers are then asked for the exact premium they are willing to pay.

\section{Methodology}

The study was carried out in Osogbo metropolis which is the capital and a local government in Osun State, Nigeria. Osogbo lies between $7^{0} 46^{1} \mathrm{~N} 4^{0} 34^{1} \mathrm{E}$. It occupies an area of $47 \mathrm{~km}^{2}$ and has a population of 156,964 [16]. Osogbo is the center of commerce, trade and agriculture in Osun State. The study area is inhabited by farmers, artisans and civil servants; and the major economic activities include farming, trading, teaching, publishing, handcrafting, ect. The study adopted a two stage sampling technique. At the first stage, stratified random sampling technique was used to stratify the population into professionals in the health sector, educational sector and civil service sector. At the second stage, purposive sampling was used to select 100 respondents and primary data were collected through the use of well structured questionnaire. The questionnaire was drawn broadly to cover information about the socio economic characteristics, knowledge and perceptions of the respondents. Some of the questions asked involved some botanical names and their common names for easy identification. The analytical methods used were descriptive statistics and Spearman's ranking method. The Descriptive statistics used frequency distribution, tables and percentages to analyze the socio-economic characteristics of the respondents. Spearman's ranking which is a non parametric measure of statistical dependence between two variables was used to analyse the level of consumers' awareness of organic vegetables as compared to inorganic vegetables as well as consumers' perception of organic vegetables. The mean values represent the average values of the respondents on each factor influencing the perception of organic vegetables which ranged from Agree, Disagree to Undecided. The highest perception was chosen based on the least mean because "Agree" was allocated the least value on coding. 


\section{Results and Discussion}

Socio economic characteristics of organic vegetable consumers in the study area

Table 1: Socio-economic Characteristics of Respondents.

\begin{tabular}{|c|c|c|}
\hline Variables & Frequency & Percentage \\
\hline \multicolumn{3}{|l|}{ Gender } \\
\hline Male & 40 & 40.0 \\
\hline Female & 60 & 60.0 \\
\hline \multicolumn{3}{|l|}{ Age (years) } \\
\hline Jan-20 & 09 & 9.0 \\
\hline $21-40$ & 65 & 65.0 \\
\hline $41-60$ & 25 & 25.0 \\
\hline 61 above & 01 & 1.0 \\
\hline Mean value & 33.28 & \\
\hline Standard Deviation & 10.94 & \\
\hline \multicolumn{3}{|l|}{ Marital Status } \\
\hline Single & 47 & 47.0 \\
\hline Married & 48 & 48.0 \\
\hline Divorce & 4 & 4.0 \\
\hline Widow & 1 & 1.0 \\
\hline \multicolumn{3}{|l|}{ Educational status (years) } \\
\hline WASSCE & 18 & 18.0 \\
\hline NCE/OND & 19 & 19.0 \\
\hline $\mathrm{HND} / \mathrm{BSc}$ & 57 & 57.0 \\
\hline MSc./Ph D & 6 & 6.0 \\
\hline \multicolumn{3}{|l|}{ Major Occupation } \\
\hline Civil servant & 59 & 59.0 \\
\hline Business/Trading & 18 & 18.0 \\
\hline Student & 12 & 12.0 \\
\hline Farming & 3 & 3.0 \\
\hline Corper & 2 & 2.0 \\
\hline Others & 6 & 6.0 \\
\hline \multicolumn{3}{|c|}{ Households monthly income (Naira) } \\
\hline No income & 12 & 12.0 \\
\hline $1-50,000$ & 62 & 62.0 \\
\hline $50,001-100,000$ & 22 & 22.0 \\
\hline $100,001-150,000$ & 2 & 02.0 \\
\hline Greater than 150,000 & 2 & 02.0 \\
\hline \multicolumn{3}{|l|}{ Household size } \\
\hline $1-5$ & 63 & 63.0 \\
\hline $6-10$ & 29 & 29.0 \\
\hline$>10$ & 8 & 08.0 \\
\hline \multicolumn{3}{|l|}{ Income spent on food } \\
\hline$<\notin 10,000$ & 53 & 53.0 \\
\hline$\$ 10,001-\$ 50,000$ & 46 & 46.0 \\
\hline$\$ 50,001-\$ 100,000$ & 1 & 01.0 \\
\hline
\end{tabular}

Source: Field Survey, 2013.
This was discussed in relation to the gender and age of the respondents, marital status, education, major occupation of household head, household income, household size, household income spend on food. From Table 1, consumers of organic vegetable were female dominated $(60.0 \%)$ with a mean age of 33 years. This indicated that consumers of organic vegetables were young and energetic people who have high propensity to consume. The finding confirms Ohen [6] who declared that this age group of respondents has a strong influence on preference and taste habit of consumers which may in turns influence their consumption pattern for fruits and vegetables. Table 1 also revealed that consumption of organic vegetable was mostly embraced by both educated single (47.0\%) and married (48.0\%) people in the study area. This result is expected to have positive influence on the perception of consumers for organic vegetable. The result affirms Dipeolu [11] who declared that the higher the educational status of people, the better they will be informed and educated people have positive perception for organic vegetable because they are more informed than the uneducated. The consumption of organic vegetable was by people of different professions but more by civil servants (59.0\%) and businessmen/women (18.0\%) who had stable source/flow of income. Table 1 also showed that the households in the study area were low income earners and it may have negative influence on their consumption of organic vegetables. This result agrees with Essoussi [17] who reported that high price of organic vegetable was one of the major factors that influence consumers to give in for conventional vegetables. Majority of consumers of organic vegetables $(63.0 \%)$ in the study area had moderate family size of 1-5 members and spend maximum of $\$ 50,000$ on food per month. The indication of this was that there was high potential market for organic vegetable in the study area because the higher the population, the higher the demand for goods and service.

\section{Perception about organic vegetables over convectional vegetables}

Table 2: Perception about Organic Vegetables over Convectional Vegetables.

\begin{tabular}{|c|c|c|}
\hline Index of Perception & Frequency & Percentage \\
\hline Healthier & & \\
\hline Disagree & 9 & 9.0 \\
\hline Undecided & 14 & 14.0 \\
\hline Agree & 77 & 77.0 \\
\hline Total & 100 & 100.0 \\
\hline Better quality & & \\
\hline Disagree & 12 & 12.0 \\
\hline Undecided & 12 & 12.0 \\
\hline Agree & 76 & 76.0 \\
\hline Total & 100 & 100.0 \\
\hline Tastier & & \\
\hline Disagree & 14 & 14.0 \\
\hline Undecided & 20 & 20.0 \\
\hline
\end{tabular}




\begin{tabular}{|c|c|c|}
\hline Agree & 66 & 66.0 \\
\hline Total & 100 & 100.0 \\
\hline More expensive & & \\
\hline Disagree & 52 & 52.0 \\
\hline Undecided & 18 & 18.0 \\
\hline Agree & 30 & 30.0 \\
\hline Total & 100 & 100.0 \\
\hline No harmful effects & & \\
\hline Disagree & 17 & 17.0 \\
\hline Undecided & 17 & 17.0 \\
\hline Agree & 66 & 66.0 \\
\hline Total & 100 & 100.0 \\
\hline
\end{tabular}

The survey in Table 2 revealed that most of the respondents had positive perception for organic vegetable as being healthier (77\%), of better quality (76\%), tastier (66\%), has no harmful effects (66\%). Interestingly, only $30 \%$ indicated that organic vegetables were more expensive than conventional vegetables. The indication of this result is that there is potential market for organic vegetable in the study area because perception does influence consumption as Dipeolu [11] reported in their work that positive perception of organic has the tendency of increasing its consumption while negative perception similarly decreases. Furthermore, this result agrees with Ohen [6] that despite the fact that consumers are aware of many positive sides of organic vegetables, yet, its consumption is still low because of high price and inconsistent supply to the market.

\section{Reasons for consumers' preference for organic vegeta- bles over conventional vegetables}

Table 3: Reasons for Consumers Preference for Organic Vegetables over Conventional Vegetables.

\begin{tabular}{|c|c|c|}
\hline Index of Preference & Frequency & Percentage \\
\hline Health consciousness & & \\
\hline Disagree & 5 & 5.0 \\
\hline Undecided & 15 & 15.0 \\
\hline Agree & 80 & 80.0 \\
\hline Total & 100 & 100.0 \\
\hline Better satisfaction & & \\
\hline Disagree & 8 & 8.0 \\
\hline Undecided & 13 & 13.0 \\
\hline Agree & 79 & 79.0 \\
\hline Total & 100 & 100.0 \\
\hline Safety & & 8.0 \\
\hline Disagree & 8 & 14.0 \\
\hline Undecided & 14 & 78.0 \\
\hline Agree & 78 & 100.0 \\
\hline Total & 100 & \\
\hline Tastier & & \\
\hline & & \\
\hline
\end{tabular}

\begin{tabular}{|c|c|c|}
\hline Disagree & 8 & 8.0 \\
\hline Undecided & 16 & 16.0 \\
\hline Agree & 76 & 76.0 \\
\hline Total & 100 & 100.0 \\
\hline \multicolumn{3}{|l|}{ Economical } \\
\hline Disagree & 20 & 20.0 \\
\hline Undecided & 13 & 13.0 \\
\hline Agree & 67 & 67.0 \\
\hline Total & 100 & 100.0 \\
\hline \multicolumn{3}{|l|}{$\begin{array}{l}\text { Environmental } \\
\text { friendly }\end{array}$} \\
\hline Disagree & 19 & 19.0 \\
\hline Undecided & 15 & 15.0 \\
\hline Agree & 66 & 66.0 \\
\hline Total & 100 & 100.0 \\
\hline \multicolumn{3}{|l|}{$\begin{array}{l}\text { Traditional } \\
\text { Agriculture }\end{array}$} \\
\hline Disagree & 16 & 16.0 \\
\hline Undecided & 18 & 18.0 \\
\hline Agree & 66 & 66.0 \\
\hline Total & 100 & 100.0 \\
\hline \multicolumn{3}{|c|}{ Highly preservative } \\
\hline Disagree & 23 & 23.0 \\
\hline Undecided & 24 & 24.0 \\
\hline Agree & 57 & 57.0 \\
\hline Total & 100 & 100.0 \\
\hline \multicolumn{3}{|c|}{ Aesthetically Pleasing } \\
\hline & 13 & 13.0 \\
\hline Undecided & 30 & 30.0 \\
\hline Agree & 57 & 57.0 \\
\hline Total & 100 & 100.0 \\
\hline
\end{tabular}

Source: Field Survey, 2013.

The result in Table 3 showed that consumers preferred organic vegetables because of their health consciousness (80\%), satisfaction derived from it (79\%), safety (78\%) and its taste (79\%). It is also revealed in Table 3 that some respondents preferred organic vegetables to conventional ones because it is economical to them. As some respondents viewed it that the more they eat organic vegetables, the lesser would be the possibility of hospital bills and drug usage. Similarly, some consumers preferred organic vegetables because they see it as environmentally friendly (66\%), encourages traditional agriculture (66\%), highly preservable (57\%) and aesthetically pleasing (57\%). These results agreed with Petrescu (2013) and Bonti and Yiridoe [18] who reported that concern for human health and safety is a key factor that influences consumer preference for organic food (vegetables). This is consistent with observed deterioration in human health over time and, therefore, motivates consumers to buy organic food (vegetables) as insurance and investment in health. 


\section{Source of Information on Organic Vegetables}

As observed in Table 4, the study showed that television (27.8) and radio (23.2) were the major sources of information on organic vegetables in the study area. $13.0 \%$ were informed through friends; $16.7 \%$ through pamphlets/newspapers and 14\% heard about it from the internet. This implies that it is easy to get information on organic vegetable in the study area and but more people are likely to be informed about it through television and radio.

Table 4: Distribution of the respondents by source of information.

\begin{tabular}{|c|c|c|}
\hline Source of information & Frequency & Percentage \\
\hline Radio & 25 & 23.2 \\
\hline Friends & 13 & 13.0 \\
\hline Television & 30 & 27.8 \\
\hline Pamphelet/Newspaper & 18 & 16.7 \\
\hline Internet & 14 & 20.3 \\
\hline
\end{tabular}

Source: Field survey, 2013.

\section{The type of organic vegetables consumed by the re- spondents}

The result in Table 5 revealed that the organic vegetables mostly consumed in the study area were Okra (21.6\%), Amaranths (20.4\%), tomato (19.8\%) and pepper (16.1\%) respectively without consideration for certification and labeling of the products. This implies that organic market in the study area is still new and underdeveloped. The result affirms Dipeolu [11] that in the event of extensive cultivation of organic vegetable, there is a ready market in the south western part of Nigeria but more education should be given on the distinction between certified and non-certified organic food.

Table 5: The types of organic vegetables consumed by the respondents.

\begin{tabular}{|c|c|c|}
\hline Types of vegetables & Frequency & Percentage \\
\hline Okro & 35 & 21.6 \\
\hline Amaranths & 33 & 20.4 \\
\hline Celosia & 3 & 2.0 \\
\hline Telfairia(fluted pumpkin) & 7 & 4.0 \\
\hline Tomato & 32 & 19.8 \\
\hline C Cucumber & 14 & 8.6 \\
\hline Pepper & 26 & 16.1 \\
\hline Lettuce & 5 & 3.5 \\
\hline
\end{tabular}

Source: Field survey, 2013.

\section{Factors influencing consumers' willingness to pay for premium for organic vegetables}

The willingness to pay the premium may be attributed to consumers' knowledge and awareness and perception of organic vegetable. The results in Table 6 show that $88 \%$ of the respondents were willing to pay premium for organic vegetables because they have eaten them at one time or the other. The finding agrees with
Thomson [19] who stated that every year, more people are getting attracted to organic foods and some are willing to pay premium on it for several reasons. Similarly, $87 \%$ of the respondents were willing to pay premium for organic vegetables because they had in one time bought organic vegetables. $80 \%$ said they would be willing to pay more for organic vegetables because they had prior knowledge of its many benefits to man, animals and the environments. $74 \%$ agreed to pay premium on organic vegetables because they had in one time or the other seen organic vegetables before and this may because of their belief in organic vegetables as aesthetically pleasing and has a higher shelf life. $64 \%$ stated that they will be willing to pay for organic vegetables because of their household size. This finding agrees with Lia [8] who stated that households with low household size have high tendency to pay premium for organic vegetables than those with large family size due to its high price. 59\% agreed that they will be willing to pay premium for organic vegetables because of their age. This therefore confirms Khaw [10] who reported that consumers are usually more health conscious as they advance in age and are willing to pay premium for good health condition [20,21].

Table 6: Factors that influence consumers' willingness to pay for organic vegetables.

\begin{tabular}{|c|c|c|c|c|}
\hline Factors & Yes (\%) & No(\%) & Mean & Score \\
\hline $\begin{array}{c}\text { Eaten organic vegetables } \\
\text { before }\end{array}$ & 88.0 & 12.0 & 1.14 & 1 st \\
\hline $\begin{array}{c}\text { Bought organic vegetables } \\
\text { before }\end{array}$ & 87.0 & 13.0 & 1.14 & 1 st \\
\hline $\begin{array}{c}\text { Prior knowledge of organic } \\
\text { vegetable }\end{array}$ & 80.0 & 20.0 & 1.21 & $3 \mathrm{rd}$ \\
\hline $\begin{array}{c}\text { Prior seeing of organic } \\
\text { vegetable }\end{array}$ & 74.0 & 26.0 & 1.28 & 4 th \\
\hline Total household income & 64.0 & 36.0 & 1.37 & 5 th \\
\hline Age & 59.0 & 41.0 & 1.41 & 6 th \\
\hline Household size & 42.0 & 58.0 & 1.59 & 9th \\
\hline
\end{tabular}

Source: Field survey, 2013.

\section{Conclusion and Recommendation}

There is high awareness and positive perception of organic vegetable among the consumers. The consumers are educated and have good access to organic vegetables but its high price was a constraint to its consumption. There is positive perception of organic vegetable among the respondents as being healthier, safer, and tastier and of better quality and most of the respondents are willing to premium on organic vegetable in the study area. These therefore show that there is a strong potential market for organic vegetables in southwest Nigeria. It is therefore recommended that programmes and facilities that will promote the expansion of organic market should be put in place in the study area.

\section{References}

1. International Federation of Organic Agriculture and Management (2004) Organic Agriculture and You. A Publication of Association of 
Organic Agriculture Practioners of Nigeria. Department of Agronomy, University of Ibadan, Nigeria.

2. Qingbin W, Jungie S (2003) Consumer Preference and Demand for Organic Food. Evidence from a Vermont Survey. Paper Presented for Presentation at the American Agricultural Economics Association Annual Meeting, Montreal, Canada, pp. 27-30.

3. Sharon F (2004) Consumer Trend for Fruit and Vegetable Products Economic \& Competitiveness Alberta's Agri-Food Industry Strategic Information Service Unit. Alberta Agriculture, Food and Rural Development, Canada.

4. Van DM, Pivonka E (2000) Overview of the health benefits of fruit and vegetable consumption for the dietetics professional: selected literature. J Am Diet Assoc 100(12): 1511-1521.

5. Stan S, Kar S, Stoner G D, Singh SV (2008) Bioactive food components and cancer risk reduction. Journal of Cell Biochem 104(1): 339-356.

6. Ohen SB, Umeze GE, Inyang EO (2014) Consumer Purchasing Behaviour for Fruits and Vegetables among Civil Servants in Essien Udim Local Government Area, Akwa Ibom State, Nigeria. Journal of Food Science and Quality Management.

7. World Health Organization (2002) The World Health Report: Reducing risks, promoting healthy life. Geneva, Switzerland.

8. Lia D, Iwan K, Denta A and James MR (2010) Consumer Preference for Indigenous Vegetables. World Agroforestry Centre, Kenya.

9. Food and Agricultural Organization (2003) Increasing Fruit and Vegetable Consumption Becomes a Global Priority.

10. Khaw K (2012) Food Safety and Supply Consumer Preference and Our Sources of Vegetables.

11. Dipeolu AO, Philip BB, Aiyelaagbe IOO, Akindode SO, TA Adedokun (2009) Consumer awareness and willingness to pay for organic vegetables in SW Nigeria, Asian. Journal of Food and Agro-Industry Special Issue pp. S57-S65.
12. Spencer H (1996) Consumer Willingness to Pay for Reduction in The Risk of Food Poisoning in UK. Journal of Agricultural Economics 47(3): 403-420.

13. Gil JM, Garcia A, Sanchez M (2000) Market segmentation and Willingness to pay for organic products in Spain. International Food and Agribusiness Management Review 3(2): 207-226.

14. Lancaster KJ (1966) A New Approach to Consumer Theory. Journal of Political Economy 74(2): 134-157.

15. James JS (2002) Research Project outline on Consumer valuation of Food quality Attributes. Office of the Dean, College of Agricultural Sciences. The Pennsylvania University.

16. National Population Commission NPC (2006) National Population Census, Federal Republic of Nigeria Official Gazette. Lagos, Nigeria, 94(4).

17. Essoussi L, Leila H, Mehdi Z (2008) Decision making process of community organic food consumers: an exploratory study. Journal of Consumer Marketing 25(2): 95-104.

18. Yiridoe EK, Bonti Ankomah S, Marti RC (2005) Comparison of consumer's perception towards organic versus conventionally produced foods: a review and update of the literature. Renewable Agriculture and Food system 20(4): 193-205.

19. Thomson R (2015) Consumers Prefer Organic Food. Huff post Food, USA.

20. Dipeolu AO, Akinbode SO (2005) Consumer Perceptions of Organic Produce in Abeokuta In FO Olasantan et al. Organic Agriculture for Sustainable Food Security Proceedings of the 1st National Conference of the Organic Agricultural Project in Tertiary Institutions in Nigeria (OAPTIN) held at the University of Agriculture, Abeokuta, Nigeria, pp. 191-196.

21. Dipeolu AO, Bello KA, SO Akinbode (2006) Comparative Economic Analysis of Organic and Inorganic Vegetable Production in Ogun State. In Okogun JA, Ade Oluwa 00, JA Adediran (eds), Proceedings of the $2^{\text {nd }}$ National Conference on Organic Agriculture in Nigeria, pp. 24-29.

\section{CC (P) This work is licensed under Creative Commons Attribution 4.0 License}

To Submit Your Article Click Here: Submit Article

DOI: $10.32474 /$ CIACR.2018.02.000141

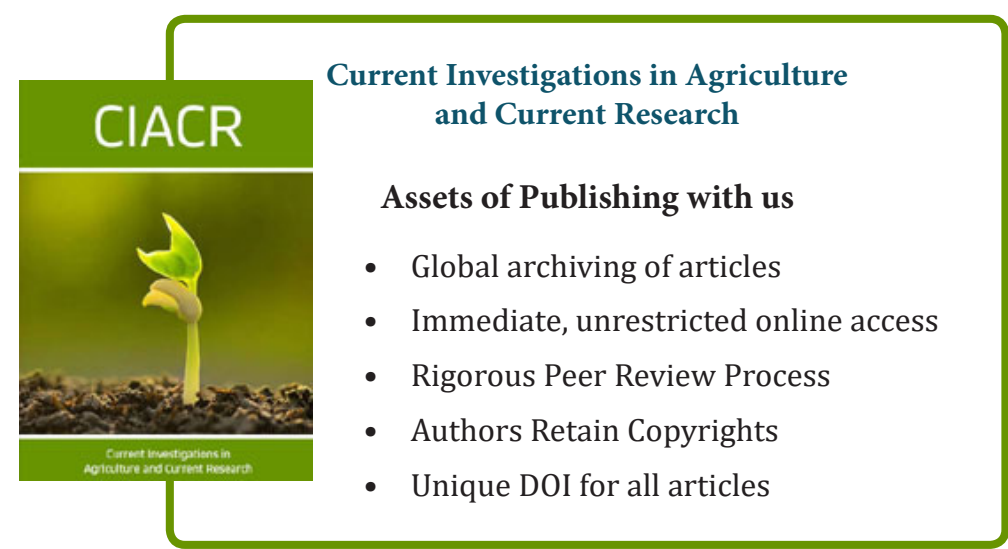

